\title{
О СОСТАВЕ ПРОДУКТА ТЕЛОМЕРИЗАЦИИ 2-ХЛОР-TRANC-3-ПЕНТЕНА С 1-ГЕКСИНОМ
}

V. TSERNOSOV, T. PEHK, H. RANG, K. LAATS. TRANS-2-KLOOR-3-PENTEENI JA 1-HEKSIINI TELOMERISATSIOONIPRODUKTI KOOSTISEST

V. TSHERNYSHOV, T. PEHK, H. RANG, K. LAATS. ABOUT THE COMPOSITION OF THE TELOMERIZATION PRODUCT OF 2-CHLOR-TRANS-3-PENTENE WITH 1-HEXYNE

Алкины присоединяют 2-бром-3-пентен по тройной связи в присутствии $\mathrm{SnCl}_{4}\left[{ }^{1}\right]$.

Нами изучена данная реакция с хлорпроизводным с использованием газо-жидкостной хроматографии $\left[{ }^{2}\right]$ и ЯМР ${ }^{13} \mathrm{C}$. По данным газохроматографического анализа в состав моноаддукта теломера 2-хлор-транс3-пентена с 1-гексином входят два соединения, которые с помощью ректификации разделить не удалось. Спектроскопией ЯМР ${ }^{13} \mathrm{C}$ установлено, что моноаддукт, полученный при теломеризации 1-гексина с 2-хлортранс-3-пентеном, состоит из изомерных $\Delta^{2,3} E, \Delta^{5,6} Z$ и $\Delta^{2,3} E, \Delta^{5,6} E-$ 6-хлор-4-метил-2,5-декадиенов (табл. 1), являющихся нормальными продуктами присоединения по правилу Марковникова. Установленные химические сдвиги ядер ${ }^{13} \mathrm{C}$ (табл. 1) соответствуют рассчитанным хими-

Таблица 1

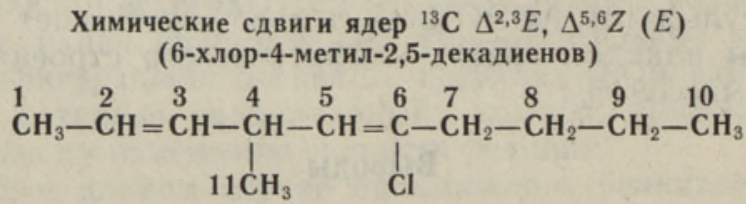

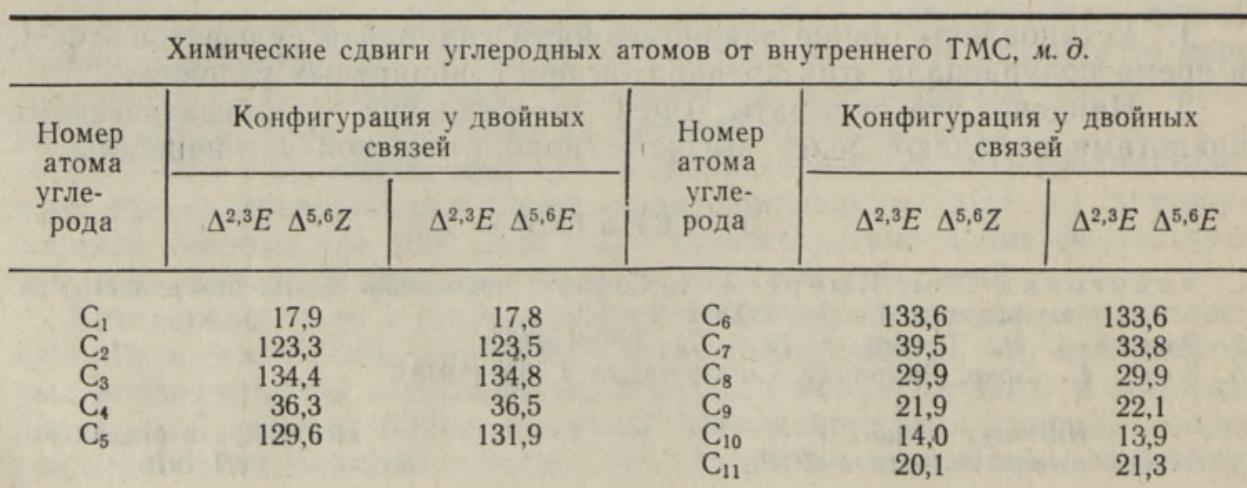


ческим сдвигам модельных алкеновых углеводородов [3] с учетом влияния атома хлора у двойной связи [4]. Как и следовало ожидать, наибольшая разница в экранировании изомеров наблюдается у $\mathrm{C}_{7}(5,7$ м.д.). Разница в экранировании у $\mathrm{C}_{4}$ незначительна, так как цци-ориентации алкильной группы и атома хлора имеют примерно одинаковое стерическое влияние [5]. Результаты теломеризации приведены в табл. 2.

Таблица 2

Теломеризация 2-хлор-транс-3-пентена с 1-гексином (катализатор - безводное хлорное олово с $1,9 \cdot 10^{-2}$ 2-моль/ $\Omega$; температура реакции $0-3 \pm 1,5^{\circ} \mathrm{C}$;

растворитель - 1,2-дихлорэтан $(50 \%)$; плотность исходной реакционной смеси $\left.\left(d^{20}\right) 0,9900\right)$

\begin{tabular}{|c|c|c|c|c|c|c|}
\hline \multirow[b]{2}{*}{$\begin{array}{c}\text { Время } \\
\text { реакцин, } \\
\text { мин }\end{array}$} & \multicolumn{4}{|c|}{ Изменение концентрации, г-моль/л } & \multirow[b]{2}{*}{$\begin{array}{l}\text { Степень } \\
\text { конвер- } \\
\text { сни, \% }\end{array}$} & \multirow{2}{*}{$\begin{array}{c}\text { Выход } \\
\text { первых } \\
\text { теломер- } \\
\text { гомологов } \\
\left(\mathrm{C}_{11}\right) \text {, } \\
\text { вес. } \% \text { от } \\
\text { теломера }\end{array}$} \\
\hline & $\begin{array}{c}\text { 2-хлор- } \\
\text { транс- } \\
\text {-3-пентен }\end{array}$ & 1-гексин & $\begin{array}{c}\Delta^{2,3} E \Delta^{5,6} Z \\
\text { 6-хлор-4- } \\
\text { метил- } \\
2,5 \text {-дека- } \\
\text { диен }\end{array}$ & $\begin{array}{c}\Delta^{2,3} E \Delta^{5,6} E \\
\text { 6-хлор-4- } \\
\text { метил- } \\
\text { 2-5-дека- } \\
\text { диен }\end{array}$ & & \\
\hline 0 & 2,64 & 2,67 & 0 & 0 & 0 & 0 \\
\hline 90 & 2,39 & 2,19 & 0,12 & 0,06 & 13,3 & 53,3 \\
\hline 180 & 2,00 & 1,78 & 0,22 & 0,15 & 28,3 & 49,2 \\
\hline 360 & 1,26 & 0,93 & 0,35 & 0,32 & 58,0 & 43,7 \\
\hline
\end{tabular}

\section{Экспериментальная часть}

Спектры ЯМР ${ }^{13} \mathrm{C}$ записаны на универсальном спектрометре [6], ра. ботающем в импульсном режиме. Накопление сигнала и Фурье-преобразования свободной процессии ядер ${ }^{13} \mathrm{C}$ проводилось с помощью ЭВМ «Nic-1080». 1-Гексин получен по методике [ $\left.{ }^{7}\right]$ и выделен ректификацией с т. кип. $82^{\circ} \mathrm{C}(767 \mu м), d_{4}^{20} 0,7145, n_{D}^{20} 1,4013$; чистота по ГЖХ состазляет 99,8\%. 2-Хлор-транс-3-пентен получен по методике [ ${ }^{8}$. Моноаддукт теломера имел следующие константы: т. кип. $75-80^{\circ}\left(4\right.$ мм), $d_{4}^{20} 0,8841$, $n_{D}^{20} 1,4592$. Относительные времена удерживания изомеров $\Delta^{2,3} E, \Delta^{5,6} Z$ и $\Delta^{2,3} E, \Delta^{5,6} E$ (6-хлор-4-метил-2,5-декадиенов) относительно геранилхлорида равны 0,39 и 0,46 .

\section{Л И ТЕ Р А Т У Р А}

1. Пет ров А. А., Ген у сов М. Л., Ионная теломеризация, М., 1968, с. 68.

2. Эр м А., К алья И., Л э э т с К., Изв. АН ЭССР, Хим. Геол., 21, 300 (1972).

3. de H a a n, J. W., van de V e n, L. J. M., Organ. Magnetic Resonance, 5, 147 (1973).

4. Li p p m a a, E., P e hk, T., Anderson, K., Rep pe, C., Organ. Magnetic Resonance, 2, 109 (1970).

5. St ot hers, I. D., Carbon-13 NMR Spectroscopy, Academic Press, New York, 1972.

6. Л и п п а а Э., Пехк Т., П а с т Я., Изв. АН ЭССР, Сер. физ.-мат., 16, 345 (1967).

7. B i i ed, E. A., Hennion, G. F., J. Amer. Chem. Soc., 59, 1310 (1937).

8. Л э э с К. В., М у к Э. А., ЖОрХ, 10, 162 (1974).

Институт химии Академии наук Эстонской ССР

Институт кибернетики Академии наук Эстонской ССР
Поступила в редакцию 19/III 1976 